(XXI век) // Археологическое наследие Урала: от первых открытий к фундаментальному научному знанию (XX Уральское археологическое совещание): мат-лы всерос. (с междунар. участием) науч. конф. Ижевск. 2016. С. 61-64.

11. Зах В.А. Хроностратиграфия неолита и раннего металла лесного Тоболо-Ишимья. Новосибирск: Наука, 2009. 320 c.

12. Мосин В.С. Этнокультурные процессы на Урале в начале голоцена // Вестник ЮУрГУ (Серия «Социально-гуманитарные науки»). 2010. № 28 (204). Вып. 15. С. 44-49.

13. Мосин В.С. Экосоциальная атаптация населения центра Северной Евразии в конце плейстоцена начале голоцена (опыт археологического моделирования) // Уральский исторический вестник. 2010. Вып. 2 (27). С. 4-12.

14. Герасименко А.А. Характеристика керамики поселения Евстюниха I // Вопросы археологии Ура- ла: сб. научных трудов. Екатеринбург; Сургут: Магеллан, 2008. Вып. 25. С. 44-72.

15. Еньшин Д.Н. Керамический комплекс поселения Мергень 7 (Нижнее Приишимье): характеристика и интерпретация // Вестник археологии, антропологии и этнографии. 2015. № 2 (29). С. 15-27.

16. Выборнов А.А., Мосин В.С., Епимахов А.В. Хронология уральского неолита // Археология, этнография и антропология Евразии. 2014. № 1 (57). С. $33-48$.

17. Косинская Л.Л. Ранняя гребенчатая керамика в неолите Зауралья // Уральский исторический вестник. 2014. № 2 (43). С. 30-40.

18. Мосин В.С. Социокультурное пространство в позднем каменном веке // Вестник Пермского университета. Серия: История. 2016. № 1(32). С. 19-27.

19. Бунькова (Герасименко) А.А. Керамика из жилища 1 поселения Полуденка 1 // Вопросы археологии Урала: сб. научных трудов. Екатеринбург; Сургут: Магеллан. Вып. 26. 2011. С. 125-140.

\title{
«BACK TO THE FUTURE»: THE MAIN HISTORIOGRAPHICAL THEMES AND TOPICAL PROBLEMS OF THE NEOLITHIC OF THE URALS
}

(C) 2017

\author{
Yakovleva Ekaterina Sergeevna, researcher \\ Archaeological Research Center (Chelyabinsk, Russian Federation)
}

\begin{abstract}
The following paper deals with some problems of Trans-Urals Neolithic which are associated with the formation and development of basic cultural and chronological concepts. Three stages in conceptual historiography are identified. The first one refers to the mid-second half of the 20th century and is associated with the formation of the first cultogenesis schemes of the late Trans-Urals Stone Age by V.N. Chernetsov, O.N. Bader and L.Ya. Krizhevskaya. At the second stage at the end of the 19th - beginning of the 21st century their ideas were revised by V.T. Kovaleva in the framework of a two-stage and two-line concept. At the same time the hypothesis of V.A. Zakh was developed. Later V.S. Mosin proposed a socio-cultural scheme for the formation of an integrated society in the Neolithic Trans-Urals. The third - the modern stage - began approximately in the second decade of the 21st century when natural scientific data growth forced to reconsider a number of established ideas about the chronology and typology of Neolithic ceramics and ornamental traditions. At the regional level there was a return to the «classical» three-term periodization; there was a trend towards regionalization of research to clarify the notions of local variants and the chronological position of material complexes, specifics of historical and cultural processes. It is concluded that it is necessary to form a new research paradigm by synthesizing middle-level theories with empirical generalizations.

Keywords: Trans-Urals; Neolithic; historiography; cultural-chronological concept; periodization; diffusionism; evolutionism; culturogenesis; empirical generalizations; research paradigm; typology; ceramic types; ornamental tradition; absolute dates.
\end{abstract}

\section{ТЕХНОЛОГИЧЕСКИЕ ОСОБЕННОСТИ НАБОРА КЕРАМИКИ ВТОРОЙ ЧЕТВЕРТИ І ТЫС. Н.Э. ПОСЕЛЕНИЯ СОСЕНКИ УЛЬЯНОВСКОЙ ОБЛАСТИ} (C) 2017

Никитина Анна Валерьевна, аспирант кафедры социологии, политологии и истории Отечества Самарский государственный технический университет (г. Самара, Российская Федерация)

Аннотащия. В статье представлена типологическая и технологическая характеристика глиняной посуды поселения Сосенки Старомайнского района Ульяновской области. Среди имеющегося материала было выделено три морфологические группы сосудов на основании внешних признаков - формы профиля и способа обработки поверхности. Дальнейший технико-технологический анализ керамики, основанный на методике А.А. Бобринского, проводился на предмет определения характеристик исходного пластичного сырья, традиций составления формовочных масс и характера обжига сосудов. Анализ подготовительной стадии гончарного процесса подтвердил наличие некоторых различий и на уровне технологии в выделенных группах. Они в основном связаны с особенностями размерности и калибровки шамота в формовочных массах. В заключение предлагается предварительно связать данный комплекс с верхнедонским культурным традициям. Однако указывается, что весьма ограниченный объем материалов пока предполагает лишь необходимость его введения в научный оборот, не делая упор на культурные интерпретации. Датировка поселения на основании массового материала не может быть определена уже, чем в пределах фаз C2-D2. Поселение относится к до- 
Никитина А.В.

именьковскому времени, а отдельные материалы, возможно, находят более поздние отголоски на памятниках Самарской Луки.

Ключевые слова: позднеримское время; гуннское время; эпоха Великого переселения народов; древнее гончарство; историко-культурный подход к изучению керамики; методика А.А. Бобринского; техникотехнологический анализ керамики; Среднее Поволжье; Старомайнский район Ульяновской области; река Урень; лесостепная зона.

В 1987 году отрядом Средневолжской археологической экспедиции под руководством М.С. Седовой проводились обследования в Старомайнском районе Ульяновской области, в ходе которых был заложен небольшой рекогносцировочный раскоп на поселении Сосенки, содержащем культурные слои эпохи бронзы и Великого переселения народов. Поселение расположено на низком песчаном берегу при впадении р. Урень в Куйбышевское водохранилище в окрестностях деревни Ивановка [1]. Коллекция находится на временном хранении в археологических фондах Самарского государственного университета.

Несмотря на небольшую площадь раскопа и немногочисленность коллекции, материалы вызывают большой интерес в вопросе определения их культурной и хронологической позиции и соотношения с известными материалами этого времени в регионе. Вещевых находок на поселении не обнаружено, однако характеристики массового материала и топографическое положение памятника свидетельствуют в пользу того, что поселение существовало в пределах фаз C2-D2 (центральноевропейской хронологии).

Сохранившаяся до настоящего времени коллекция очень невелика - около 130 фрагментов керамических сосудов и сковород, 1 фрагмент глиняного горнового сопла (рис. 1: 18), несколько шлаков от переработки железной руды. Для более детального рассмотрения были отобраны профильные части сосудов и фрагменты сковород. Описание керамического комплекса включает в себя морфологическую группировку керамики с приведением известных аналогий. Технологические определения основываются на применение методик, существующих в рамках историко-культурного подхода к изучению древней керамики [2; 3]. Наблюдения выполнялись при помощи бинокулярного микроскопа «Микромед MC1 вар. 1B».

\section{Типология}

По особенностям профилировки и фактуры поверхности можно охарактеризовать несколько типов встречаемых сосудов.

Tun 1 (сосуды № 1, 2). Горшок с небольшой вертикальной (слегка отогнутой) шеей большого диаметра и сильно раздутыми круглыми плечами (рис. 1: 1). Переход между шеей и плечом резкий. Оба сосуда имеют тонкие стенки по сравнению с остальной керамикой раскопа. Поверхность сосудов залощена, направление лощения горизонтальное.

Ближайшие аналогии подобным формам известны единично - на селище Карлинское I Самарской Луки [4, с. 229, рис. 2: 11]. Подобные сосуды, но с чуть более плавными переходами между конструктивными частями, встречаются на селищах Бахилово $[5$, c. 66 , рис. $4: 1,2]$ и Жигулевск I, единично такая форма в чернолощеном варианте происходит с селища Ош-Пандо-Нерь.

Tun 2 (Сосуды № 3, 4, 8, 12-15). Сосуды имеют относительно узкое горло, отогнутый венчик и высокое прямое плечо (рис. 1: 3-5, 8, 11, 12). Сосуды этой группы имеют грубую поверхность: примеси не вдавлены, следы обработки специальными инструментами практически отсутствуют. Стенки сосудов относительно толстые. Данный тип составляет основу комплекса.

Несколько похожих по форме сосудов происходит с селища Славкино, однако практически у всей славкинской керамики присутствует внутреннее ребро или утолщение при переходе от шеи к плечу, что не позволяет делать аналогию прямой. Близкие формы венчиков встречаются в материалах Тимяшевского селища $[4$, с. 145 , рис. 99: 1,$4 ; 6$, с. 139 , рис. 93: 1] и, возможно, на селище Новая Беденьга [7, с. 184, рис. 15]. Такой тип также распространен среди памятников Верхнего Дона: на поселении Замятино-8 [8, с. 202 , рис. $17: 3$, с. 203 , рис. $18: 1-4$, с. 208 , рис. 23: 3-4], а также имеют распространение среди лепной керамики черняховской культуры. Непосредственно в киевской традиции такие формы встречаются заметно реже, нежели в вариантах синкретичных культурных образований.

В отдельном варианте (сосуд № 4) шея сосуда сужено сильнее, чем у основной массы образцов. В Среднем Поволжье подобная форма происходит с селища Старокуйбышеское III [9, с. 25], также подобные варианты встречается и на Верхнем Дону поселении Ксизово-19 [10, с. 509, рис. 147: 9, с. 512, рис. 152: 2, 4].

Tun 3 (сосуды № 9, 10, 12). Верхние части сосудов с плавной $\mathrm{S}$-образной профилировкой, венчик короткий слегка отогнутый. Плечо невысокое, переход от плеча к тулову начинается достаточно высоко, по сравнению с типом 2. Возможно, эти фрагменты принадлежат мискам, однако достоверно сказать об этом нельзя. Все образцы данной группы имеют характерную обработку поверхности: все примеси хорошо вдавлены и не выступают на внешней поверхности, сама поверхность обработана кожаным инструментом, обработка всплошную покрывает всю поверхность. Венчики таких форм имеют широкое распространение на памятниках Среднего Поволжья, хотя их фактура является не самой характерной.

Также в материалах встречены фрагменты сосудов с прямыми (цилиндрическими) достаточно небольшой толщины венчиками (рис. 1: 6, 14, 19). Однако их небольшой размер не позволяет судить о форме сосудов даже гипотетически.

Кроме этого один из отобранных образцов (№ 11) занимает промежуточное положение между типами 2 и 3, но имеет при этом обработку поверхности, характерную для типа 2. 

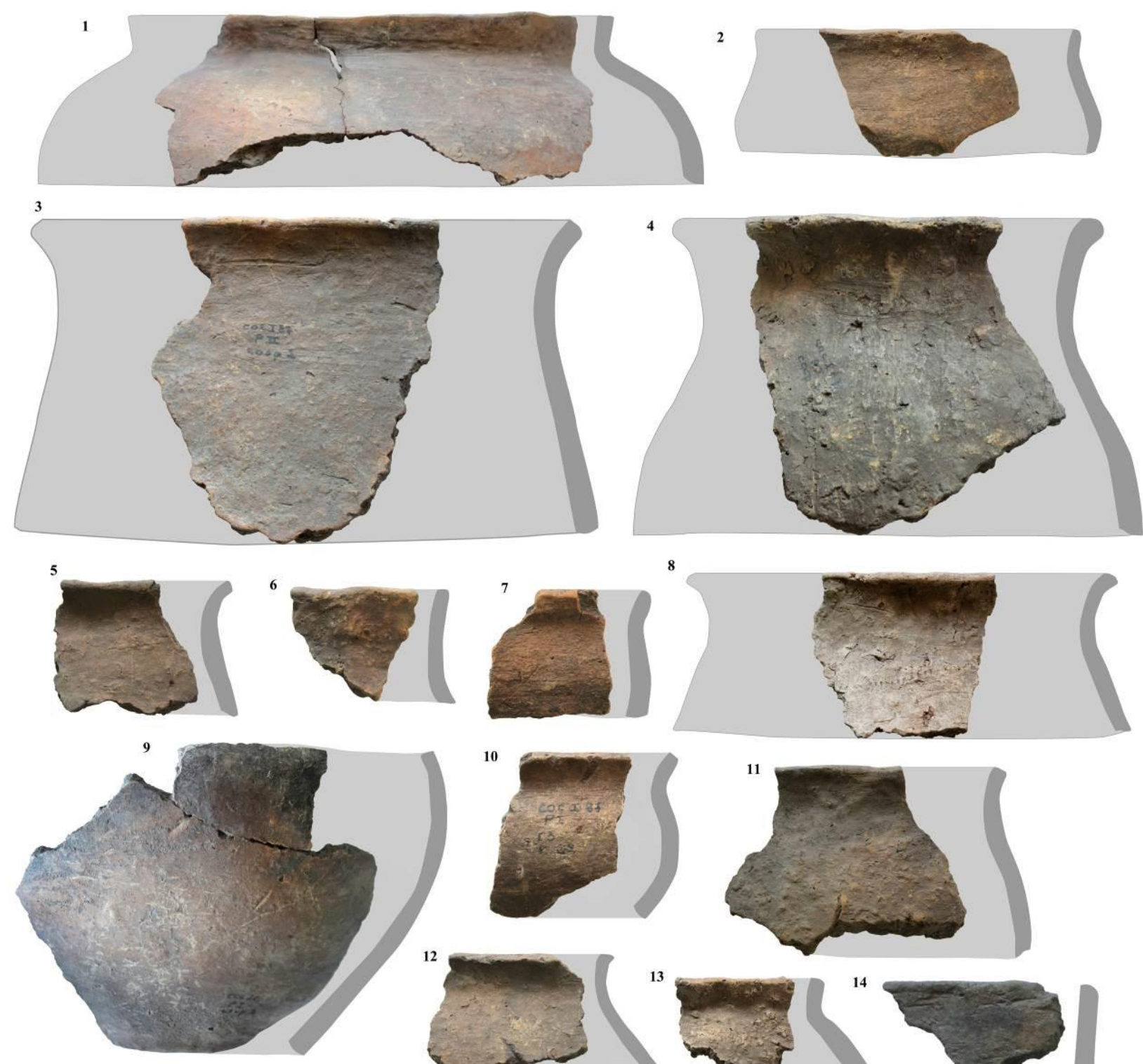

10
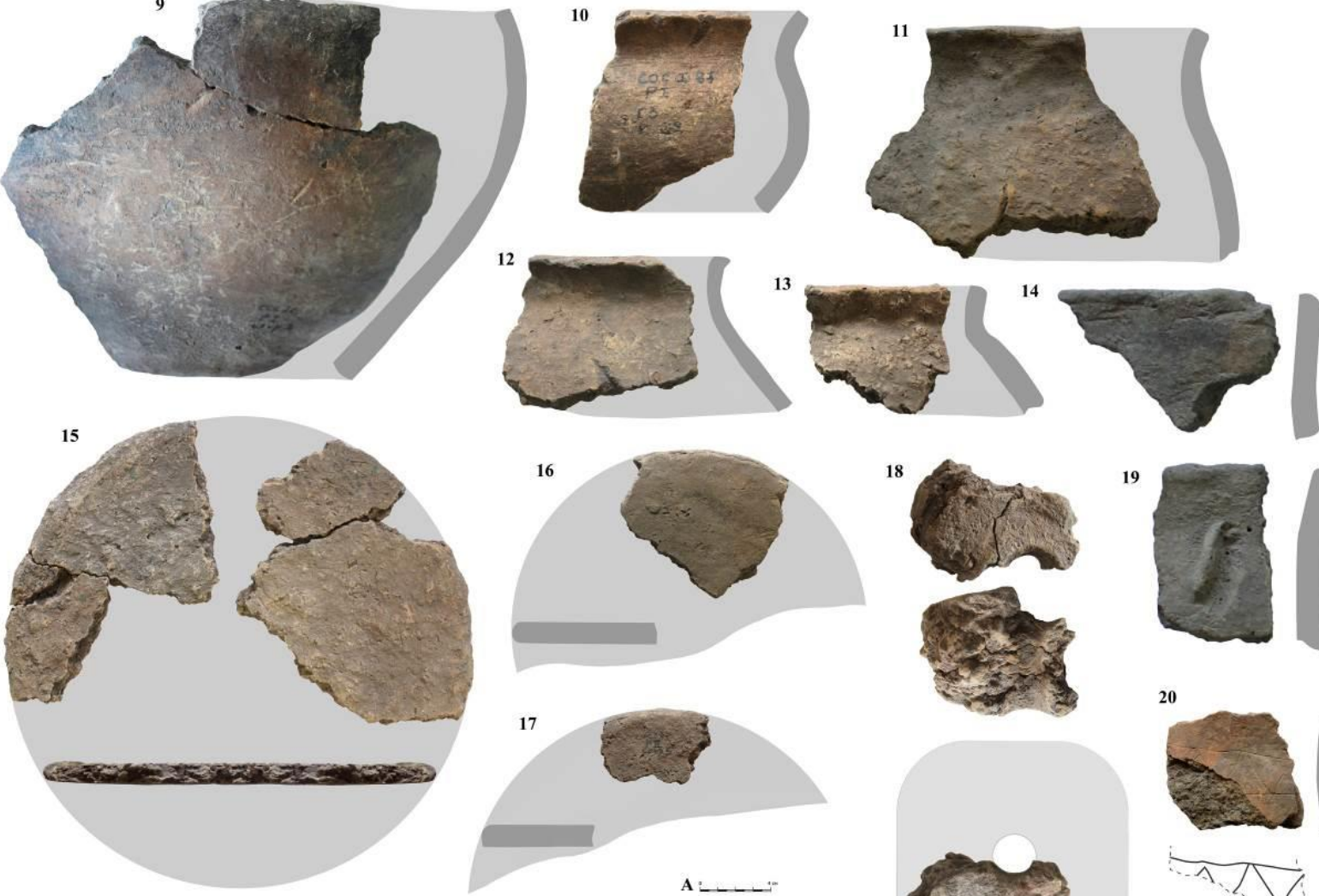

19
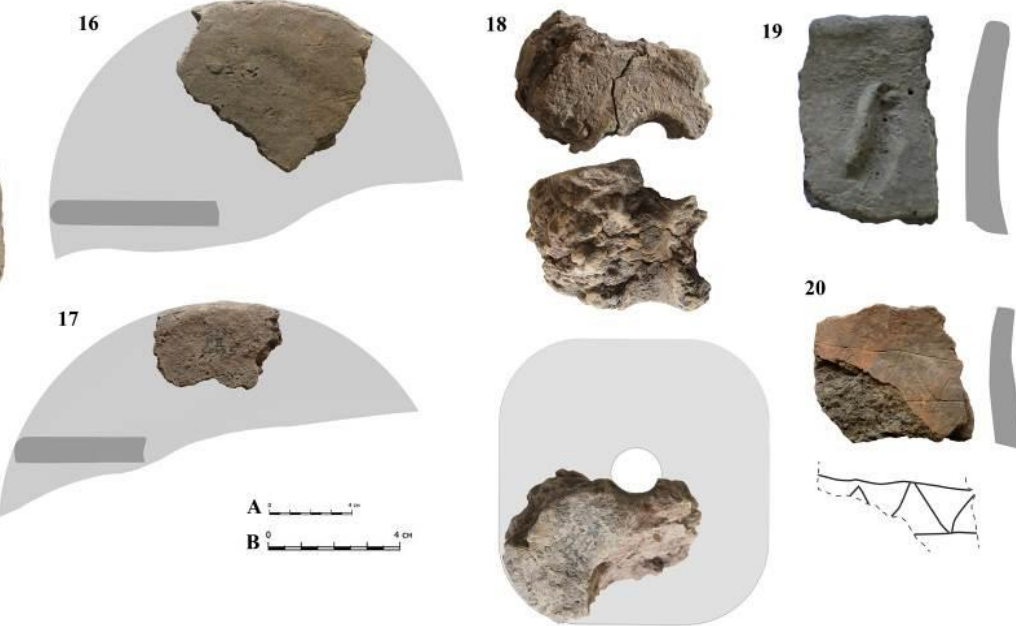

20

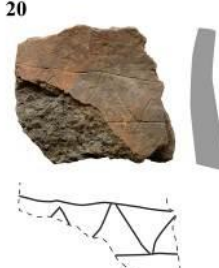

Рисунок 1 - Керамика поселения Сосенки.

1 - сосуд № $2 ; 2$ - № 9; 3- № 3; 4- № 4; 5- № 14; 6- № $16 ; 7$ - № $12 ; 8$ - № 8; 9 - № $1 ; 10$ - № 10 ;

11 - № $13 ; 12$ - № 15; 13- № 11; 14, 19- 6.н.; 15-17- сковороды; 15- № 5; 16 - № 18; 17- № 20;

18 - фрагмент глиняного сопла; 20 - № 7. Масштабы: $A$ - к позициям 15-18; $B$ - к позициям 1-14, 19-20

Сковороды. Встречены фрагменты от 4 сковород. Сковорода № 18 (рис. 1: 16) имеет ровную заглаженную поверхность, нет следов подсыпок, край округлый и покатый. Две сковороды № 5 и № 20 имеют грубую поверхность, следы подсыпки на дне и слегка уплощенный край (рис. 1: 15, 20). Четвертая сковорода имеет бортик, однако он изготовлен путем оттягивания и приподнятия края, а не уплощения 
Никитина А.В.

края и защипывания излишка глины, как это можно увидеть на сковородах именьковского времени. Сковороды без бортика можно достоверно считать ранними, они встречаются на всех известных памятниках позднеримского и гуннского времени и практически отсутствуют на памятниках именьковской культуры.

\section{Технологические особенности}

Исходное пластичное сырье. В рассмотренной керамике было зафиксировано использование одного (условного) сорта исходного пластичного сырья. Это ожелезнённая, незапесоченная и не алевритовая, но достаточно пористая, «рыхлая» по фактуре глина. Единично в качестве естественной примеси в ней встречаются фракции мелкого кварцевого песка и оолитовый бурый железняк. В одном из сосудов (№ 6) сырье более пористое и зернистое, насыщенное естественными обломочными компонентами, чем в остальных.

Формовочные массы всех рассмотренных сосудов и сковород изготовлены с добавлением в исходное пластичное сырье шамота и органики (рис. 2). Шамот применен в 3 вариантах: А) мелкий шамот до 0,9 мм в концентрации 1:6-7 (обр. № 4, 6, 7, 9, 10, 12, $18,20) ;$ В) средний шамот до 1,2 мм в концентрации 1:5 (обр. № 1-3, 13,16); С) крупный шамот до 4 мм в концентрации 1:3 (обр. № 8, 11, 14, 15). При этом можно проследить некоторые закономерности. Среди 3-го морфологического типа сосудов встречен только вариант А соотношения размера и концентрации шамота. Также все сковороды соответствуют варианту А. Вариант С применялся только во 2-й группе сосудов. Вариант В присутствует в сосудах как 1-й, так и 2-й группы. Во всех случаях шамот был изготовлен из той же глины, что и сосуд. Органика во всех сосудах представлена в невысокой концентрации и, по-видимому, в жидком или влажном состоянии. В отдельных сосудах, помимо аморфных или мелких каплевидных пустот и пор, которые встречены во всех образцах, удалось зафиксировать единичные следы растительных компонентов, представленные короткими обрубками стеблей растений - № 2, 13, 20.

Обжиг. Все сосуды обожжены в окислительной газовой среде. Однако выдержка сосудов в температурах каления разнится (рис. 3). Выдержка сосудов № 4, 10, 11, 14, при температурах каления была минимальна - менее 5 минут, т.к. глубина прокаленного слоя глины не превышает 1 мм. Наиболее многочисленная группа (сосуды 1-3, 7-9, 12, 13, 15, 16, 18) находилась при температурах каления длительное время (не менее 20 мин.). Только два образца - № 6 и № 20 - прокалены полностью, т.е. находились в высоких температурах более часа.

Таким образом, морфологические и технологические особенности свидетельствуют о том, что состав населения был глубоко синкретичен и насчитывал в своем составе, как минимум, 3 разных источника традиций. Однако тот факт, что все эти традиции на момент их нахождения на рассматриваемом поселении приспособились к одному источнику пластичного сырья, возможно, косвенно свидетельствует о том, что данная поликультурность образовалась еще до пере- селения в регион, а в момент отложения находок в культурный слой находилась в адаптивном состоянии.

Неоднократные отсылки к Верхнедонским аналогиям достаточно набросочны, в связи с немногочисленностью и фрагментарностью рассматриваемого материала. Однако стоить упомянуть, что помимо более субъективных критериев, таких как формы сосудов, на присутствие мигрантов с Верхнего Дона в Среднем Поволжье указывают и более яркие, как, например, орнамент на сосудах, который в эту эпоху является исключительным признаком за его редкостью. К таким можно отнести фрагменты подправленных на круге кувшинов с зигзагообразным орнаментом на плече с Тимяшевского селища и городища Лбища, находящие многочисленные аналогии в замятинском и ксизовском комплексе памятников [8, с. 249 , рис. $64: 7,8$, с. 302 , рис. $117: 3,6 ; 10$, с. 515 , рис. 155: 2], а также в керамике черняховской культуры. Вероятно, к подражанию этим мотивам относится рассмотренный в Сосенском комплексе сосуд № 7. Другим отличительным видом декора являются сосуды с налепными валиками, орнаментированными насечками, обнаруженные на селищах Крепость Кондурча [6, с. 121, рис. 74: 8-9], Севрюкаево II [11, табл. 68], Старокуйбышевское III [9, с. 25]. Наиболее близкой территорией, на которой встречается подобный декор, также является Верхний Дон [8, с. 276, рис. 91: 2]. Хотя такие сосуды встречаются и на черняховских памятниках Поднестровья $[12$, с. 230 , табл. LV: 22, с. 231, табл. LVI: 3]. В любом случае, подобный орнамент, наиболее вероятно, возникает как подражание валикам на черняховских гончарных вазах и кувшинах, а значит, его истоки необходимо искать у групп населения, непосредственно с ней контактировавших.

В настоящий момент сложно говорить о доминировании киевской культурной традиции, по крайней мере для данного памятника, как это принято определять для многих других синхронных памятников региона. В первую очередь, это обусловлено тем, что наряду с формами сосудов, которые можно трактовать как киевские, присутствуют и другие типы, не распространённые в классических вариантах киевской культуры. Наиболее типичной киевской формы - открытого слабопрофилированного биконического сосуда с широким устьем, здесь мы не видим. Напротив, диаметры всех венчиков очень небольшие, что свидетельствует в пользу того, что формы были ближе к сосудам закрытого типа. Такие формы гораздо ближе к черняховской лепной традиции. Вовторых, наряду с традицией добавления шамота в формовочные массы, в гончарстве киевской культуры достаточно широко распространены рецепты с дресвой. В рассмотренных нами материалах, как и в других материалах лесостепного Поволжья этого периода, рецепты с дресвой распространения не имеют, так же как и не имеют широкого распространения в черняховской лепной традиции [13, с. 115].

Mbl приносим благодарность автору раскопок М.С. Седовой, а также сотрудникам археологических фондов СамГУ В.А. Скарбовенко и П.В. Ломейко за предоставленную возможность использования материалов. 
Никитина А.В.
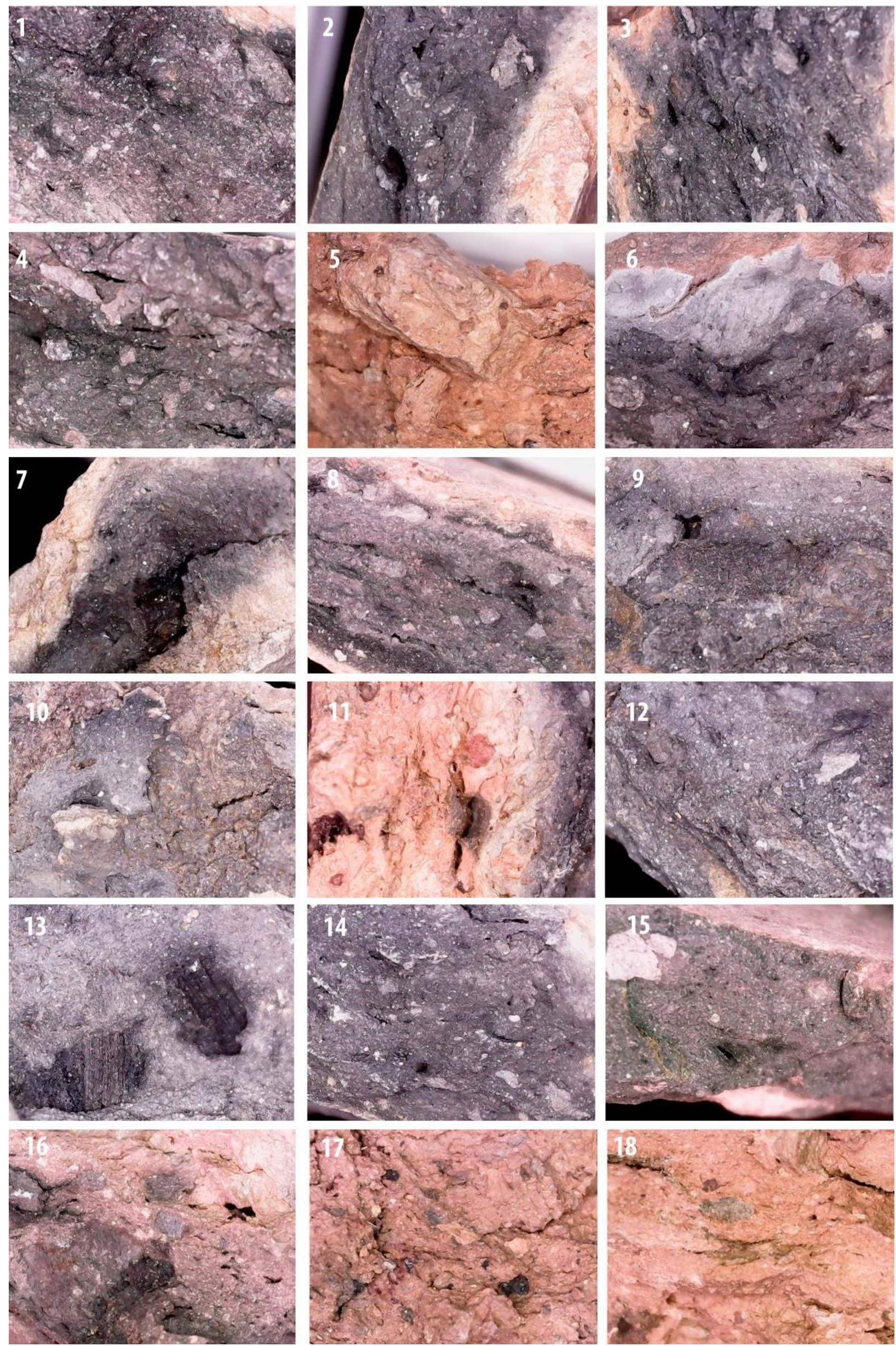

Рисунок 2 - Микрофотосъемка анализируемых образцов керамики.

1 - сосуд № $1 ; 2$ - № 2; 3- № 3; 4- № 4; 5- № 5; 6- № 7; 7- № 8; 8- № 9; 9- № 10; 10 - № 11 ; 11 - № $12 ; 12$, 13 - № $13 ; 14$ - № $14 ; 15$ - № $15 ; 16$ - № $16 ; 17$ - № $18 ; 18$ - № 20 
1

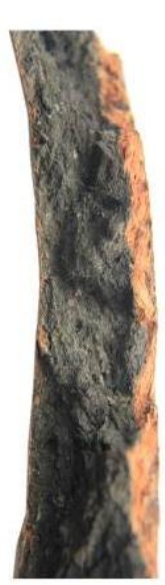

7

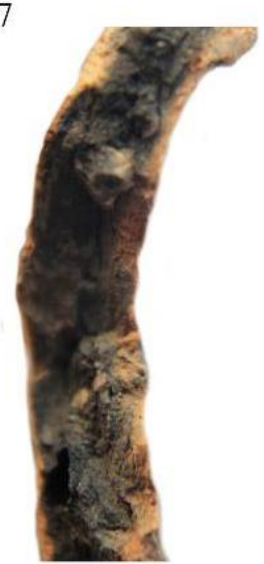

12

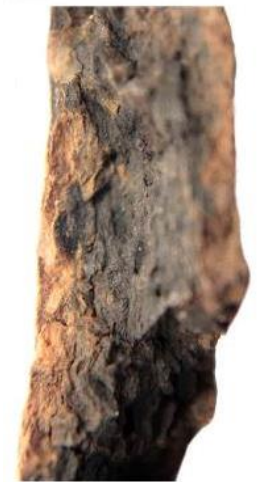

2

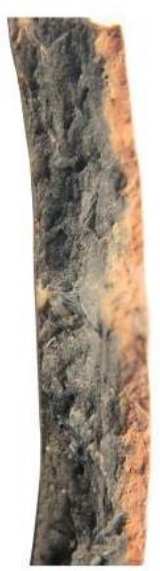

8

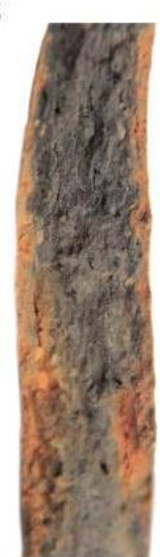

3

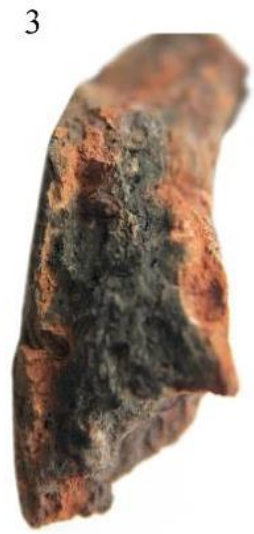

9

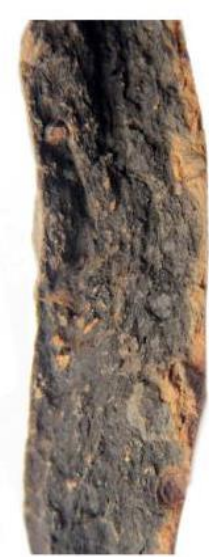

4

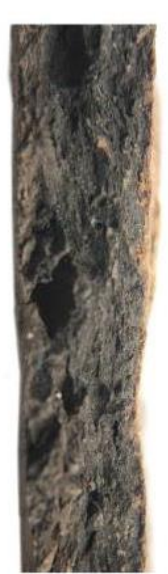

10

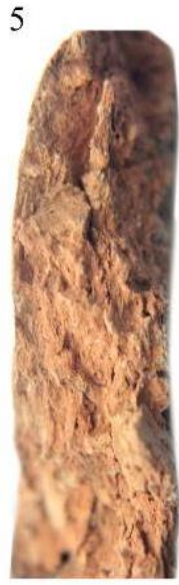

11

6
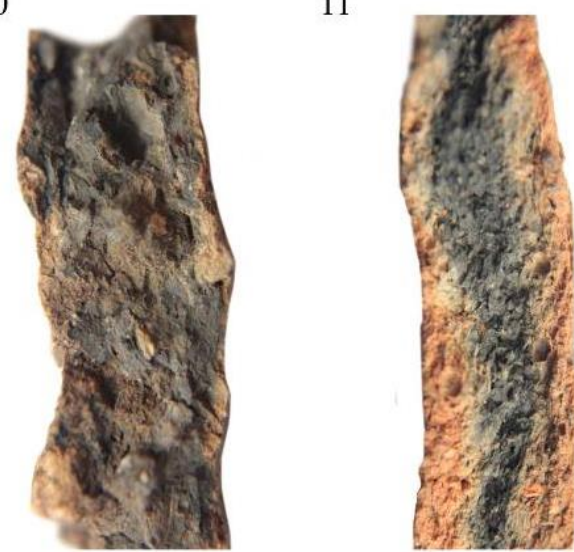

16

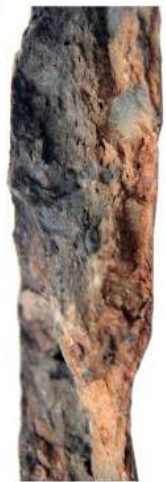

17

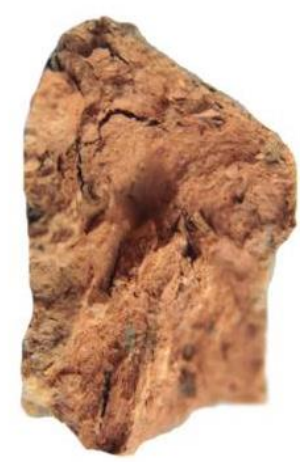

Рисунок 3 - Обжиг сосудов. 1 - сосуд № $1 ; 2$ - № $2 ; 3$ - № 3; 4- № 4; 5- № 5; 6- № 7; 7- № 8; 8- № 9; 9- № $10 ; 10$ - № $11 ; 11$ - № 12;12 - № $13 ; 13$ - № $14 ; 14$ - № 15; 15 - № $18 ; 16$ - № 16; 17- № 20

\section{СПИСОК ЛИТЕРАТУРЫ:}

1. Седова М.С. Отчет о раскопках археологических памятников в зоне строительства Старомайнской оросительной системы в Ульяновской области 1987 г. / Научно-отраслевой архив Института археологии РАН, Р-1 11932.

2. Бобринский А.А. Актуальные проблемы изучения древнего гончарства: коллективная монография. Самара: Изд-во СамГПУ, 1999. 233 с.

3. Цетлин Ю.Б. Древняя керамика. Теория и методы историко-культурного подхода. М.: ИА РАН, 2012. $384 \mathrm{c}$.

4. Сташенков Д.А. Об абсолютной дате памятников именьковской культуры на Самарской Луке // Поволжская археология. Казань: ФЭН, 2016. № 3 (17). С. 225-246.

5. Матвеева Г.И., Никитина А.В. Бахиловское селище эпохи великого переселения народов на (по ма- териалам исследований Г.И. Матвеевой 1992 г.) // Вояджер: мир и человек: теоретический и научно-методический журнал. № 7. Самара: Самарский государственный технический университет, 2016. С. 56-72.

6. Сташенков Д.А. Оседлое население Самарского лесостепного Поволжья в I-V веках н.э. (Раннеславянский мир. Вып. 7.). М.: ИА РАН, 2005. 150 с.

7. Вязов Л.А., Семыкин Ю.А. Городище и селище Новая Беденьга: эпоха Великого переселения народов в Ульяновском Предволжье. Ульяновск: НИИ истории и культуры им. Н.М. Карамзина, 2016. 227 с.

8. Обломский А.М. Поселение Замятино-7 // Острая Лука Дона в древности. Замятинский археологический комплекс гуннского времени (Раннеславянский мир. Выпуск 6). М.: ИА РАН, 2004. С. 37-56.

9. Валиев Р.Р., Вязов Л.А., Серых Д.В., Ситдиков А.Г. Новый памятник Великого переселения народов в Западном Закамье // Археологические иссле- 
дования 2016 г.: Болгар и Свияжск. Казань: ИД «Казанская недвижимость», 2016. С. 24-25.

10. Обломский А.М., Козмирчук И.А. Поселение позднеримского и гуннского времени Ксизово-19 // Острая Лука Дона в древности. Археологический комплекс памятников гуннского времени у с. Ксизово (конец IV-V в.) Раннеславянский мир. Выпуск 16. М.: ИА РАН, 2015. С. 75-133.

11. Скарбовенко В.А. Отчет о раскопках селища Севрюкаево II в Ставропольском районе Самарской области в 2003 году. Самара, 2003 / Научный архив археологической лаборатории Самарского государственного университета.

\section{TECHNOLOGICAL FEATURES OF CERAMIC COMPLEX OF 2ND FOURTH OF I MILLENNIUM AD OF SOSENKI SETTLEMENT IN THE ULYANOVSK REGION}

(C) 2017

Nikitina Anna Valerievna, postgraduate student of Sociology, Politology and Russian History Department Samara State Technical University (Samara, Russian Federation)

Abstract. The following paper deals with typological and technological analyses of the pottery of the Sosenki settlement of the Ulyanovsk region. The author identified 3 morphological groups of vessels among the available material on the basis of external features that are based on vessels shape and surface treatment. Technical-andtechnological analysis of ceramics, based on the methods of A.A. Bobrinsky, was carried out for the purpose of determining the characteristics of the initial raw material, traditions of composing the pasts and the character of the calcination of the vessels. The analysis of the preparatory stage of the pottery process confirmed the presence of some differences in the selected groups mainly related to the features of the dimension and calibration of grog in the paste. In conclusion, it is proposed to assign this complex to the Upper Don cultural traditions. However, it is pointed out that a very limited amount of material still requires only the introduction of a scientific use without focusing on cultural interpretations. Settlement dating based on mass material can not be determined smaller than within the C2-D2 phases. The settlement dates back to the pre-Imenkovo period and materials may find later echoes on the sites of Samara Bend.

Keywords: Late Roman period; D2 period; Great Migration period; ancient pottery; historical-and-cultural approach of ceramics study; method of A.A. Bobrinsky; technical-and-technological analysis of ceramic; Middle Volga region; archeology of Ulyanovsk region; Staromaynsky district; Uren river; Forest-steppe area.

УДК 902/904 (903.02)

Статья поступила в редакцию 18.06.2017

\section{НЕКОТОРЫЕ ИТОГИ ПЕТРОГРАФИЧЕСКОГО ИССЛЕДОВАНИЯ КЕРАМИКИ С ПОСЕЛЕНИЯ ТОКСАНБАЙ}

(C) 2017

Шевнина Ирина Викторовна, научный сотрудник археологической лаборатории

Костанайский государственный университет им. А. Байтурсынова (г. Костанай, Республика Казахстан)

Лошакова Татьяна Николаевна, старший научный сотрудник

Институт археологии имени А.Х. Маргулана (2. Алматы, Республика Казахстан)

Аннотация. Исследование посвящено изучению исходного сырья и формовочных масс керамических изделий с поселения Токсанбай. Целью исследования являлось изучение технологических аспектов при изготовлении керамических сосудов, углубленное изучение исходного сырья и формовочных масс керамики гончаров поселения. При исследовании образцов, кроме петрографического анализа, фрагменты керамики изучались с использованием метода бинокулярной микроскоскопии, проведены химические опыты (микрометодом) с применением молибдена аммония и соляной кислоты, проверены микрореакциями на железо в составе черепка. Полученный результат выявил, что исходным сырьем служила ожелезненная глина, а химическая реакция на Fe всех фрагментов оказалась положительной. Исходная глина запесоченна, кроме этого в составе песка отмечены полевые шпаты, обломки песчаников, окремненных сланцев и эпидот. Выявлено три рецепта формовочных масс. Органика фиксируется в виде окремненных пустот. Состав органики определен, как карбонатно-кремнистый или карбонатно-фосфатный. Анализ на микрореакции с применением молибдена аммония $\left(\mathrm{MoH}_{4}\right)_{2} \mathrm{AmO}_{4}$ определил наличие в образцах органики фосфатного типа. Из органических наполнителей у части исследуемых образцов были выявлены пустоты округлой и овальной формы от выгоревшей органики. Исследование керамики поселения будет продолжено, но можно утверждать, что токсанбайские гончары использовали местную глину, а самой распространенной примесью являлся органогенный известняк. 